\title{
THE BENEFIT OF ENTROPY IN THE MANAGEMENT OF GENERAL ANAESTHESIA FOR THE PATIENTS WITH METABOLIC DISORDERS
}

\author{
CĂLIN TIMAR ${ }^{1,2 \#}$, PETRE COTRAU $^{1,2}$, CRISTIAN DAINA $^{1,2}$, RALUCA JUNCAR $^{2}$, ALIN $^{2}$ \\ TEUȘDEA $^{3 *}$, LAURA VICAS $^{2}$, ELEONORA MARIAN $^{2 \#}$, ANDREEA MARGARETA VLAD ${ }^{2}$, \\ MIHAI JUNCAR ${ }^{2}$ \\ ${ }^{1}$ Emergency County Hospital Oradea, Department of Anaesthesia and Intensive Care (ATI1), 65-67 Gheorghe Doja Street, \\ Oradea, Romania \\ ${ }^{2}$ Faculty of Medicine and Pharmacy, University of Oradea, 10 Decembrie Square, Oradea, Romania \\ ${ }^{3}$ Faculty of Environmental Protection, University of Oradea, 23 Gen. Magheru Street, Oradea, Romania
}

*corresponding author: ateusdea@gmail.com

${ }^{\#}$ Authors with equal contribution.

Manuscript received: December 2020

\begin{abstract}
This study shows the role of entropy in general anaesthesia for the patient and the hospital in order to reduce the need for volatile gases (sevoflurane), but also of hypnotic and opioids, bringing major benefits to the patient, and the economy of the hospital significantly reducing the costs of anaesthesia and the number of days spent in the hospital, also avoiding postoperative complications related to anaesthesia. We conducted a study over half a year (2018) for 30 patients who need general anaesthesia from a total of 1536 patients available within the host institution, and meet the inclusion criteria for monitoring the entropy, patients who were subsequently divided into 3 study groups: 10 patients in group 1 (patients with metabolic disorders obesity and/or diabetes mellitus), 10 in the group 2 (without metabolic disorders) and 10 in the control group 3 (patients under general anaesthesia without monitoring entropy). In this study we have shown that entropy reduces the use of intrasurgical anaesthetics in patients with metabolic disorders (diabetes and/or obesity) with almost 20\% compared with the control group, so entropy provided them with a reduction of the need for anaesthetics and a much faster postoperative awakening, diminishing the number of hospitalization days for these patients, greatly reducing postoperative costs and complications due to comorbidities.
\end{abstract}

\section{Rezumat}

Studiul prezent arată rolul entropiei în anestezia generală pentru pacient și spital pentru a reduce nevoia de gaze volatile (sevofluran), dar și de hipnotice și opioide, aducând beneficii majore pacientului și economiei spitalului, reducând semnificativ costurile anesteziei și numărul de zile petrecute în spital, evitând, de asemenea, complicațiile postoperatorii legate de anestezie. A fost efectuat un studiu observațional prospectiv pe o jumătate de an (2018), pentru 30 de pacienți care au avut nevoie de anestezie generală dintr-un total de 1536 pacienți disponibili în cadrul instituției gazdă și îndeplinesc criteriile de includere în studiu pentru monitorizarea entropiei, pacienți care au fost împărțiți ulterior în 3 grupuri de studiu: 10 pacienți în grupul 1 (pacienți cu tulburări metabolice obezitate și/ sau diabet zaharat), 10 în grupul 2 (fără tulburări metabolice) și 10 în grupul 3 de control (pacienți sub anestezie generală fără monitorizarea entropiei). În acest studiu am arătat că entropia reduce utilizarea anestezicelor intraoperatorii la pacienții cu tulburări metabolice (diabet și/sau obezitate) cu aproape $20 \%$ față de cei din grupul de control, astfel încât entropia le-a oferit o reducere a necesității de anestezice și o trezire postoperatorie mai rapidă, diminuarea numărului de zile de spitalizare, reducând de asemenea mult costurile postoperatorii și complicațiile datorate comorbidităţilor.

Keywords: entropy, general anaesthesia, metabolic disorders, sevoflurane, opioids

\section{Introduction}

Anaesthetic drugs such as opioids, propofol and benzodiazepines are all well known to have exaggerated responses in patients with obstructive sleep apnoea (OSA). They may decrease pharyngeal musculature tone, which is essential in maintaining airway patency [13]. Commonly used anaesthetic drugs can be dosed according to total body weight or ideal body weight based on lipid solubility. The volume of distribution is changed in obese patients with regard to lipophilic drugs. This is especially true of benzodiazepines and barbiturates, among the commonly used anaesthetic drugs [14].

Three exceptions to this rule are digoxin, procainamide and remifentanil, which even though highly lipophilic, have no relationship with the properties of the drug and their volume of distribution. Consequently, dosing of commonly used anaesthetic drugs such as propofol, vecuronium, rocuronium and remifentanil is based on ideal body weight. In contrast, thiopental, midazolam, succinylcholine, atracurium, cisatracurium, fentanyl 
and sufentanil should be dosed on the basis of total body weight. Another caveat to this recommendation is that maintenance doses of propofol should be based on total body weight and, conversely, on ideal body weight for sufentanil $[15,17]$. The choice of volatile agents is based on the physical characteristics of tissue solubility, expressed as blood-gas partition coefficients and fat-blood partition coefficients. Some evidence suggests that desflurane may be the anaesthetic of choice because of a more consistent and rapid recovery profile that is seen with sevoflurane and propofol [3]. However, a more recent study has suggested that the difference in immediate recovery between sevoflurane and desflurane is not clinically significant. Even though nitrous oxide provides some analgesic effect and is eliminated rapidly, we prefer to avoid it because of the high oxygen demand in the obese [11].

The ability to monitor the levels of patient consciousness while undergoing general anaesthesia is clinically important because an inadequate level of anaesthesia can result in patient intra-operative awareness, an overdose of anaesthesia can result in a prolonged recovery and an increased risk of postoperative complications [10]. The use of depth anaesthesia monitors is claimed to provide a more accurate assessment of the level of anaesthesia and aid the tailoring of the anaesthetic dose to the individual patient. Tailored dosing potentially reduces drug consumption and the number of adverse effects, with possibly faster emergence from anaesthesia with an earlier patient discharge from the recovery room [2]. Entropy is one of the most important steps in the complex management of patients allowing the modulation of anaesthesia for every patient needs. We also believe that by individualizing the anaesthesia by monitoring the entropy it is possible to obtain an appropriate management for hemodynamic complications during anaesthesia including tachycardia, bradycardia, hypotension and hypertension.

The purpose of this study is to determine the influence of entropy as an anaesthetic method on substance use in patients with type 2 diabetes and obesity [8].

\section{Materials and Methods}

We conducted a prospective and descriptive observational study, using direct clinical observations, over half a year (2018) for 30 patients who needed general anaesthesia from a total of 1536 patients available within the Emergency County Hospital Oradea, Romania and meet the inclusion criteria for monitoring the entropy. Patients were subsequently divided into 3 groups of 10 patients each: in group 1 patients with metabolic disorders obesity and/or diabetes mellitus, the group 2 patients without metabolic disorders and control group 3 patients without monitoring entropy.
The consent of the patients/relatives has been taken (as the case may be) and the treatment was performed according to the hospital's internal treatment guidelines. Inclusion criteria in the study: age: between 18 years and 80 years; gender: male and female; American Society of Anesthesiologists (ASA) physical status I (a normal healthy patient), II (a patient with mild systemic diseases), III (a patient with severe systemic diseases) [9].

In this study we excluded: cardiac pacemaker; atrial fibrillation at the time of presentation; any subject with an epidural catheter, placed pre-operatively; allergy to propofol or any other anaesthetic drug; pregnancy; the presence of neuromuscular diseases; the presence of neurologic diseases [8].

We employed in the three groups of patients undergoing general anaesthesia a number of variables such as: age, sex, anaesthetic duration (in minutes), change of heart rate baseline at $10 \mathrm{~min}$, change of systolic blood pressure baseline at 10 minutes, the use of sevoflurane $(\mathrm{mL})$, fentanyl $(\mathrm{mg})$, rocuronium $(\mathrm{mg})$ and propofol $(\mathrm{mg})$ and a flow of fresh gases amounting to $2 \mathrm{~L} / \mathrm{min}(50 \%$ oxygen and $50 \%$ air).

At the end of anaesthesia, we calculated the total consumption of intrasurgical anaesthetics for each patient and for the patient groups. Evaluating the impact of general anaesthesia guided with entropy on the hemodynamic instability represented and characterized by high blood pressure episodes (hypertension), or low blood pressure (hypotension) and by high cardiac rate (tachycardia), or low cardiac rate (bradycardia).

Statistical analysis

The samples are presented in 3 groups: BMI/DM with entropy (group 1), normal BMI with entropy (group 2) and normal BMI without entropy (group 3). Each group contains data from 10 patients. Statistical analysed variables were: sevoflurane, rocuronium, fentanyl, propofol and BMI.

Univariate statistical analysis was performed using one-way ANOVA (Analysis of Variance) with the Minitab 16 (Minitab Inc., USA). The pairwise comparisons were done with the Tukey's post hoc test; statistical significance for this test was chosen $\mathrm{p}=0.05$.

Multivariate analysis was involved to test the clustering possibility of the sample groups. For this task a multivariate sequence was used: PCA (Principal Component Analysis), LDA (Linear Discriminant Analysis) and MANOVA (Multivariate ANOVA), with a statistical significance of $\mathrm{p}=0.05$. The multivariate analysis was performed with PAST $4.03[6,17]$.

\section{Results and Discussion}

The minimum age of patients included in the study with diabetes and obesity in the first study group was 31 years, and the maximum age was 78 with a mean of 53.5 years, and the characteristics of the variables 
FARMACIA, 2021, Vol. 69, 5

followed are presented in Table I. Table II presents the intraoperative clinical features under general anaesthesia of patients without metabolic disorders and entropy monitoring from group 2.

Table I

Intraoperative clinical features under general anaesthesia of patients with metabolic disorders and entropy monitoring (group 1)

\begin{tabular}{|c|c|c|c|c|c|c|c|c|c|}
\hline $\begin{array}{c}\text { Sex/Age } \\
\text { (years) }\end{array}$ & BMI/DM & $\begin{array}{l}\text { HR before } \\
\text { intubation }\end{array}$ & $\begin{array}{l}\text { TAS before } \\
\text { intubation }\end{array}$ & $\begin{array}{c}\text { Entropy } \\
\text { RE/SE } \\
\text { before IOT }\end{array}$ & $\begin{array}{c}\text { OR } \\
\text { time } \\
(\min )\end{array}$ & \begin{tabular}{|c|} 
Sevoflurane \\
$(\mathrm{mL})$
\end{tabular} & $\begin{array}{c}\text { Rocuronium } \\
\text { (mg) }\end{array}$ & $\begin{array}{c}\text { Fentanyl } \\
\text { (mg) }\end{array}$ & $\begin{array}{l}\text { Propofol } \\
\text { (mg) }\end{array}$ \\
\hline $\mathrm{F} / 39$ & 34/DM & 94 & 131 & $94 / 89$ & 85 & 18 & 60 & 0.40 & 150 \\
\hline $\mathrm{M} / 78$ & 38/DM & 92 & 163 & 99/89 & 225 & 104 & 110 & 0.40 & 150 \\
\hline $\mathrm{M} / 39$ & $32 / \mathrm{DM}$ & 91 & 141 & $99 / 91$ & 50 & 17 & 50 & 0.60 & 150 \\
\hline $\mathrm{M} / 49$ & 39/DM & 83 & 150 & $97 / 89$ & 240 & 56 & 200 & 0.65 & 300 \\
\hline $\mathrm{F} / 58$ & 37/DM & 71 & 122 & $97 / 87$ & 50 & 16 & 50 & 0.20 & 160 \\
\hline $\mathrm{F} / 31$ & 33/DM & 81 & 131 & $98 / 90$ & 50 & 18 & 50 & 0.20 & 170 \\
\hline $\mathrm{M} / 66$ & $40 / \mathrm{DM}$ & 63 & 130 & $96 / 85$ & 45 & 13 & 40 & 0.35 & 100 \\
\hline $\mathrm{M} / 56$ & $35 / \mathrm{DM}$ & 60 & 116 & $95 / 88$ & 60 & 13 & 50 & 0.30 & 180 \\
\hline F/56 & 41/DM & 130 & 180 & $95 / 88$ & 60 & 16 & 50 & 0.30 & 150 \\
\hline F/62 & 33/DM & 87 & 171 & $96 / 85$ & 240 & 73 & 100 & 0.65 & 150 \\
\hline $\begin{array}{c}\text { Average } \\
54.4 \text { years }\end{array}$ & & & & Total & 1105 & 344 & 760 & 4.05 & 1660 \\
\hline
\end{tabular}

State Entropy (SE); Response Entropy (RE); TAS (Arterial Systolic Tension); HR (Heart Rate); OR (Operation Time); IOT (Orotracheal intubation); BMI (Body Mass Index); DM (Diabetes mellitus)

Table II

Intraoperative clinical features under general anaesthesia of patients without metabolic disorders and entropy monitoring (group 2)

\begin{tabular}{|c|c|c|c|c|c|c|c|c|}
\hline Sex/Age & $\begin{array}{l}\text { HR before } \\
\text { intubation }\end{array}$ & $\begin{array}{l}\text { TAS before } \\
\text { intubation }\end{array}$ & $\begin{array}{c}\text { Entropy RE/SE } \\
\text { before IOT }\end{array}$ & $\begin{array}{l}\text { OR time } \\
(\mathrm{min})\end{array}$ & $\begin{array}{c}\text { Sevoflurane } \\
(\mathrm{mL})\end{array}$ & $\begin{array}{c}\text { Rocuronium } \\
(\mathrm{mg})\end{array}$ & $\begin{array}{c}\text { Fentanyl } \\
\text { (mg) }\end{array}$ & $\begin{array}{c}\text { Propofol } \\
\text { (mg) }\end{array}$ \\
\hline $\mathrm{F} / 34$ & 130 & 127 & $100 / 91$ & 60 & 18 & 40 & 0.30 & 120 \\
\hline $\mathrm{F} / 31$ & 75 & 134 & $97 / 91$ & 70 & 20 & 50 & 0.35 & 150 \\
\hline M/64 & 47 & 128 & $96 / 88$ & 105 & 17 & 110 & 0.40 & 120 \\
\hline $\mathrm{F} / 70$ & 70 & 189 & $100 / 89$ & 150 & 20 & 80 & 0.60 & 60 \\
\hline $\mathrm{F} / 57$ & 65 & 133 & $99 / 90$ & 120 & 19 & 70 & 0.30 & 170 \\
\hline $\mathrm{F} / 19$ & 107 & 124 & $100 / 89$ & 45 & 12 & 40 & 0.30 & 80 \\
\hline $\mathrm{M} / 68$ & 73 & 148 & $97 / 88$ & 60 & 14 & 40 & 0.25 & 150 \\
\hline $\mathrm{M} / 60$ & 75 & 129 & $99 / 89$ & 45 & 16 & 35 & 0.25 & 150 \\
\hline $\mathrm{M} / 74$ & 75 & 140 & $97 / 91$ & 60 & 22 & 50 & 0.30 & 180 \\
\hline $\mathrm{F} / 58$ & 95 & 150 & 99/98 & 230 & 78 & 50 & 0.45 & 150 \\
\hline $\begin{array}{c}\text { Average } \\
53.5 \text { years }\end{array}$ & & & Total & 945 & 236 & 565 & 3.5 & 1330 \\
\hline
\end{tabular}

State Entropy (SE); Response Entropy (RE); TAS (Arterial Systolic Tension); HR (Heart Rate); OR (Operation Time); IOT (Orotracheal intubation)

Table III

Clinical and intraoperative characteristics under general anaesthesia of patients without entropy monitoring (group 3/control group)

\begin{tabular}{|c|c|c|c|c|c|c|c|c|}
\hline Sex/Age & $\begin{array}{l}\text { HR before } \\
\text { intubation }\end{array}$ & $\begin{array}{l}\text { TAS before } \\
\text { intubation }\end{array}$ & $\begin{array}{c}\text { Entropy RE/SE } \\
\text { before IOT }\end{array}$ & $\begin{array}{c}\text { OR time } \\
(\mathrm{min})\end{array}$ & $\begin{array}{c}\text { Sevoflurane } \\
(\mathrm{mL})\end{array}$ & $\begin{array}{c}\text { Rocuronium } \\
\text { (mg) }\end{array}$ & $\begin{array}{c}\text { Fentanyl } \\
\text { (mg) }\end{array}$ & $\begin{array}{c}\text { Propofol } \\
\text { (mg) }\end{array}$ \\
\hline $\mathrm{F} / 55$ & 78 & 119 & No monitor & 180 & 33 & 110 & 0.40 & 150 \\
\hline $\mathrm{M} / 33$ & 88 & 158 & No monitor & 105 & 44 & 60 & 0.35 & 150 \\
\hline $\mathrm{F} / 35$ & 109 & 167 & No monitor & 200 & 40 & 50 & 0.40 & 120 \\
\hline $\mathrm{M} / 62$ & 85 & 190 & No monitor & 98 & 16 & 70 & 0.30 & 150 \\
\hline $\mathrm{M} / 64$ & 85 & 130 & No monitor & 110 & 30 & 60 & 0.35 & 200 \\
\hline$F / 36$ & 73 & 130 & No monitor & 230 & 45 & 200 & 0.50 & 250 \\
\hline $\mathrm{F} / 35$ & 109 & 167 & No monitor & 200 & 40 & 180 & 0.40 & 150 \\
\hline $\mathrm{M} / 35$ & 95 & 142 & No monitor & 230 & 84 & 120 & 0.50 & 200 \\
\hline $\mathrm{M} / 33$ & 88 & 158 & No monitor & 100 & 44 & 60 & 0.35 & 150 \\
\hline $\mathrm{F} / 55$ & 78 & 119 & No monitor & 180 & 33 & 110 & 0.40 & 180 \\
\hline $\begin{array}{c}\text { Average } \\
44.3 \text { years }\end{array}$ & & & Total & 1633 & 409 & 1020 & 3.95 & 1700 \\
\hline
\end{tabular}

State Entropy (SE); Response Entropy (RE); TAS (Arterial Systolic Tension); HR (Heart Rate); OR (Operation Time); IOT (Orotracheal intubation) 
The patients' characteristics in the control group are presented in Table III, the minimum age being 33 years and the maximum age 64 years, with an average of 43.3 years.
At the end of anaesthesia, we calculated the total consumption of intrasurgical anaesthetics for each patient and for patients groups according to Figure 1 and Figure 2.

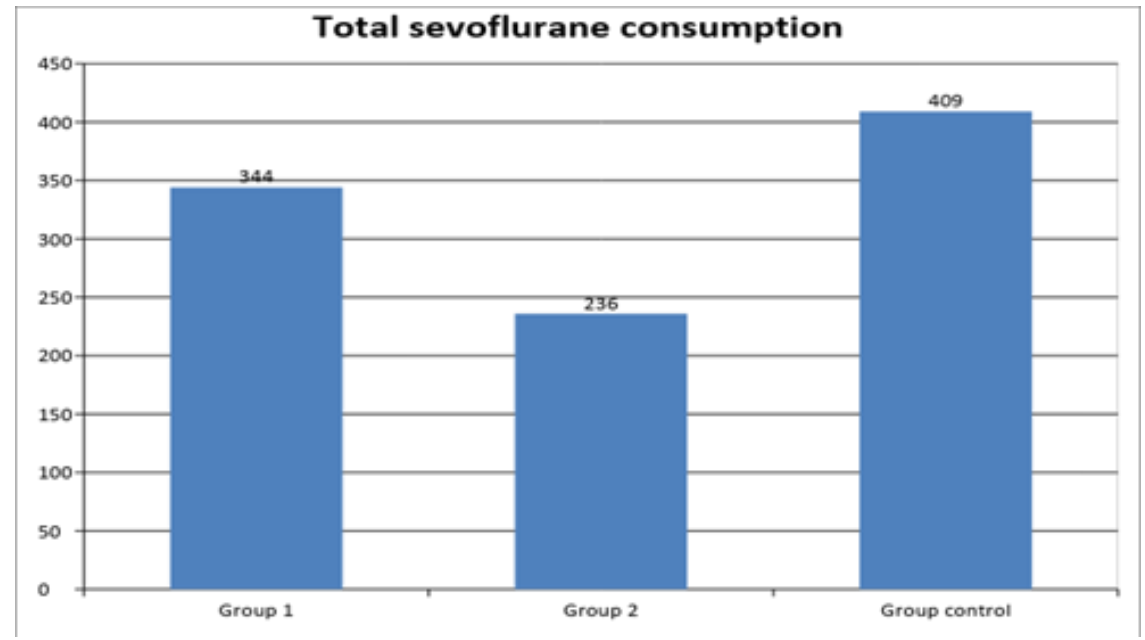

Figure 1.

Total sevoflurane consumption $(\mathrm{mL})$ in the three groups of patients monitored

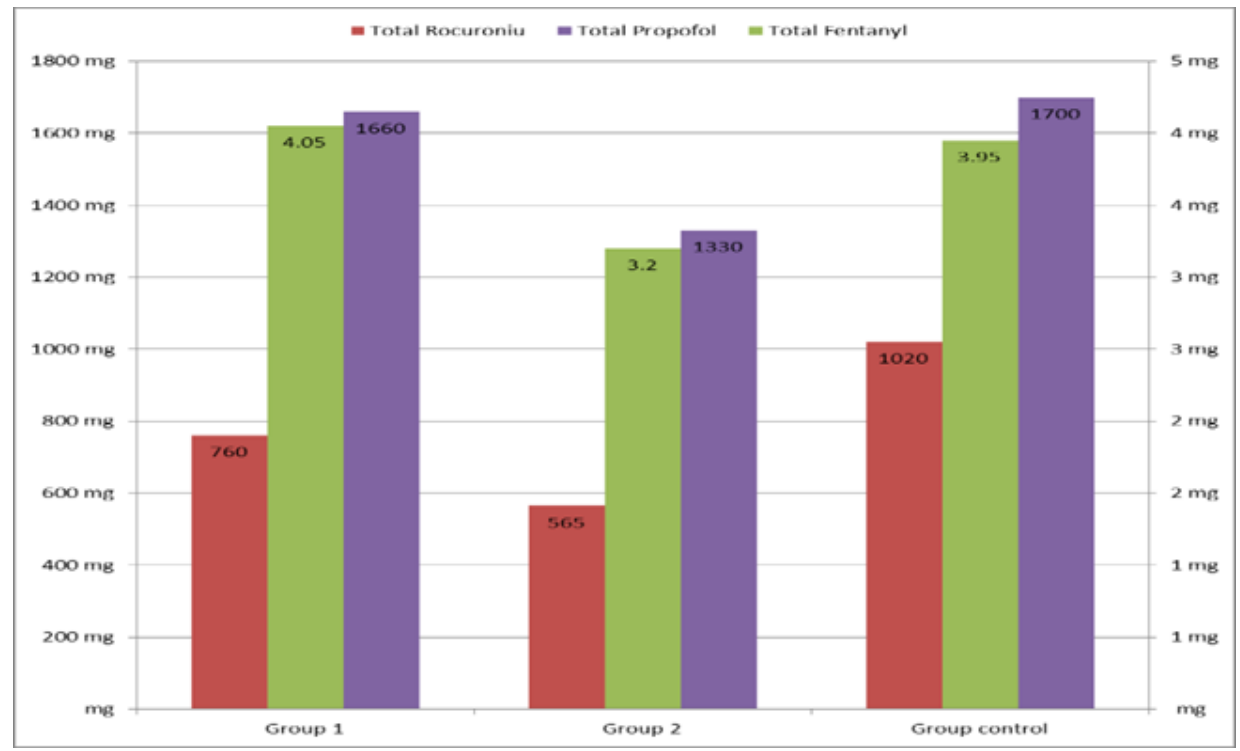

Figure 2.

Total consumption of rocuronium (mg) - red, propofol (mg) - green and fentanyl (mg) - purple, in patients in the three groups

Entropy is a device which helps analysing the EEG (electroencephalogram) and contains state entropy (SE) and response entropy (RE). SE is computed from the electroencephalogram in the 0.8 to $32 \mathrm{~Hz}$ range and should encompass mainly the hypnotic elements of the electroencephalogram, whereas response entropy is computed from 0.8 to $47 \mathrm{~Hz}$, which includes a significant amount of the facial electromyography (EMG). Thus when EMG activity is low, state entropy and response entropy should be the same, but with stimulation and an increase in facial EMG, response entropy should increase. The initial clinical studies with this device showed that it produced results comparable to those of the Bispectral Index (BIS) when tested with intravenous and inhaled hypnotic anaesthetics [16]. The General Electric (GE) entropy module uses the same unilateral self-adhesive fronto-temporal sensor as the BIS, but specifically made for the GE product (i.e., they are not interchangeable). The module works only with GE monitoring systems with the appropriate software loaded. The SE, RE and a single channel of the raw electroencephalogram are displayed on the same screen as the other monitored variables. The displayed state entropy range is 0 (isoelectric EEG) to 91 (fully awake), and the response entropy range is 
0 to 100 . The anaesthetic range is 40 to 60 , and the manufacturer recommends that state entropy outside this range may require a change in hypnotic dosing, whereas if the state entropy is in this range but the response entropy is more than 10 above the state entropy, more analgesic may be required [7].

The GE Entropy ${ }^{\mathrm{TM}}$ Module is indicated for adult and paediatric patients older than 2 years within a hospital for monitoring the state of the brain by data acquisition of EEG (electroencephalograph) and FEMG (frontal electromyograph) signals. The spectral entropies, response entropy (RE) and state entropy (SE), are processed EEG and FEMG variables. In adult patients, response entropy and state entropy may be used as an aid in monitoring the effects of certain anaesthetic agents, which may help the user to titrate anaesthetic drugs according to the individual needs of adult patients. Furthermore, in adults the use of entropy parameters may be associated with a reduction of anaesthetic use and faster emergence from anaesthesia. The entropy measurement is to be used as an adjunct to other physiological parameters. Entropy is a measure of irregularity in any signal $[1,4,5]$.

The results obtained in our study are clinically meaningful, with RE-SE difference of less than 10. Sevoflurane requirements are reduced with $16 \%$ and rocuronium with $25.5 \%$ at the patients with metabolic disorders and entropy monitoring than the control groups without entropy, while maintaining hemodynamic stability. This implies that one can use, based on patient weight, larger amounts of benzodiazepines, fentanyl, or sufentanil, althrough these drugs are best titrated to the desired clinical effect. Conversely, based on real body weight, smaller amounts of propofol are needed to anaesthetize the patient. With vecuronium or rocuronium, the initial dose should be based on ideal body weight, followed by the state of neuromuscular blockade. Complete blockade in the morbidly obese is necessary not just for surgeons' convenience, but also to facilitate mechanical ventilation. The drug chosen is not as important as the state of paralysis $[12,16,18]$.

This study shows the role of entropy in general anaesthesia for the patient and the hospital in order to reduce the need for volatile gases (sevoflurane) but also of hypnotic and opioids, bringing major benefits to the patient, and the economy of the hospital significantly reducing the costs of anaesthesia and reducing the number days spent in hospital, also avoiding postoperative complications related to anaesthesia.

With this study we demonstrate that the role of entropy in general anaesthesia for the patient safety is mandatory. The ability to monitor the levels of patient consciousness reduces the risk of an inadequate level of anaesthesia and intra-operative awareness which can cause significant suffering followed by post-traumatic stress disorder in some patients. Conversely, an overdose of anaesthesia can result in a prolonged recovery and an increased risk of postoperative complications and costs including permanent cognitive dysfunction for some patients. Furthermore and wider studies considering entropy are needed, because it has so many benefits to offer for medicine.

The statistical results were performed with original data (not pre-processed) of intrasurgical anaesthetics and BMI and BMI normalized intrasurgical anaesthetics values. This sequence was performed to emphasizes the hypothesis that the entropy monitoring decreases the intrasurgical anaesthetics quantities at such level that "statistically equalize" the DM group with the other that is without DM, but with entropy monitoring. The statistical univariate results of original data are presented in Tables IV, V, VI and VII and Figures $3,4,5$ and 6 . The results of BMI normalized data are presented in Tables VIII, IX, X and XI and Figures 7, 8, 9 and 10 .

The comparison of intrasurgical anaesthetics original values with and without entropy monitoring and DM condition are presented statistically and graphically in Table IV and Figure 3. Figure 4 shows the relative differences between the values of the group1 and group 2, respecting the group 3 values (group 3 was the control group). All the entropy monitored groups have lower relative differences than the control group (group 3), but the one for fentanyl and group 1, that has $2.5 \%$ higher relative difference than group 3 . Despite this latter relative difference, the results from Table IV depict statistically not significant differences (at significance level $\mathrm{P}=0.05$ ) from all pairwise intrasurgical anaesthetics mean values comparisons. Also, from all pairwise BMI mean values comparisons (last column in Table IV) there are statistically significant differences as it was prescribed in the design of experiment, between group 1 with DM condition and other two analysed groups without DM.

Table IV

Mean values ( \pm standard deviation) of intrasurgical anaesthetics and BMI for the analysed patient groups -

\begin{tabular}{|c|c|c|c|c|c|}
\hline Group & Sevoflurane $(\mathbf{m L})$ & Rocuronium $(\mathbf{m g})$ & Fentanyl $(\mathbf{m g})$ & Propofol $(\mathbf{m g})$ & BMI \\
\hline Group 1 & $34.400 \mathbf{a} \pm 30.388$ & $76.000 \mathbf{a} \pm 46.947$ & $0.405 \mathbf{a} \pm 0.163$ & $166.000 \mathbf{a} \pm 48.826$ & $36.200 \mathbf{a} \pm 3.059$ \\
\hline Group 2 & $23.600 \mathbf{a} \pm 18.353$ & $56.500 \mathbf{a} \pm 22.366$ & $0.350 \mathbf{a} \pm 0.102$ & $133.000 \mathbf{a} \pm 36.346$ & $24.300 \mathbf{b} \pm 2.648$ \\
\hline Group 3 & $40.900 \mathbf{a} \pm 16.610$ & $102.000 \mathbf{a} \pm 50.160$ & $0.395 \mathbf{a} \pm 0.061$ & $170.000 \mathbf{a} \pm 35.777$ & $24.800 \mathbf{b} \pm 3.250$ \\
\hline
\end{tabular}

Different letters across columns for each variable denotes statistically significant differences between the samples means (Tukey's post hoc test). Results are expressed as mean \pm standard deviation $(\mathrm{n}=10)$. 


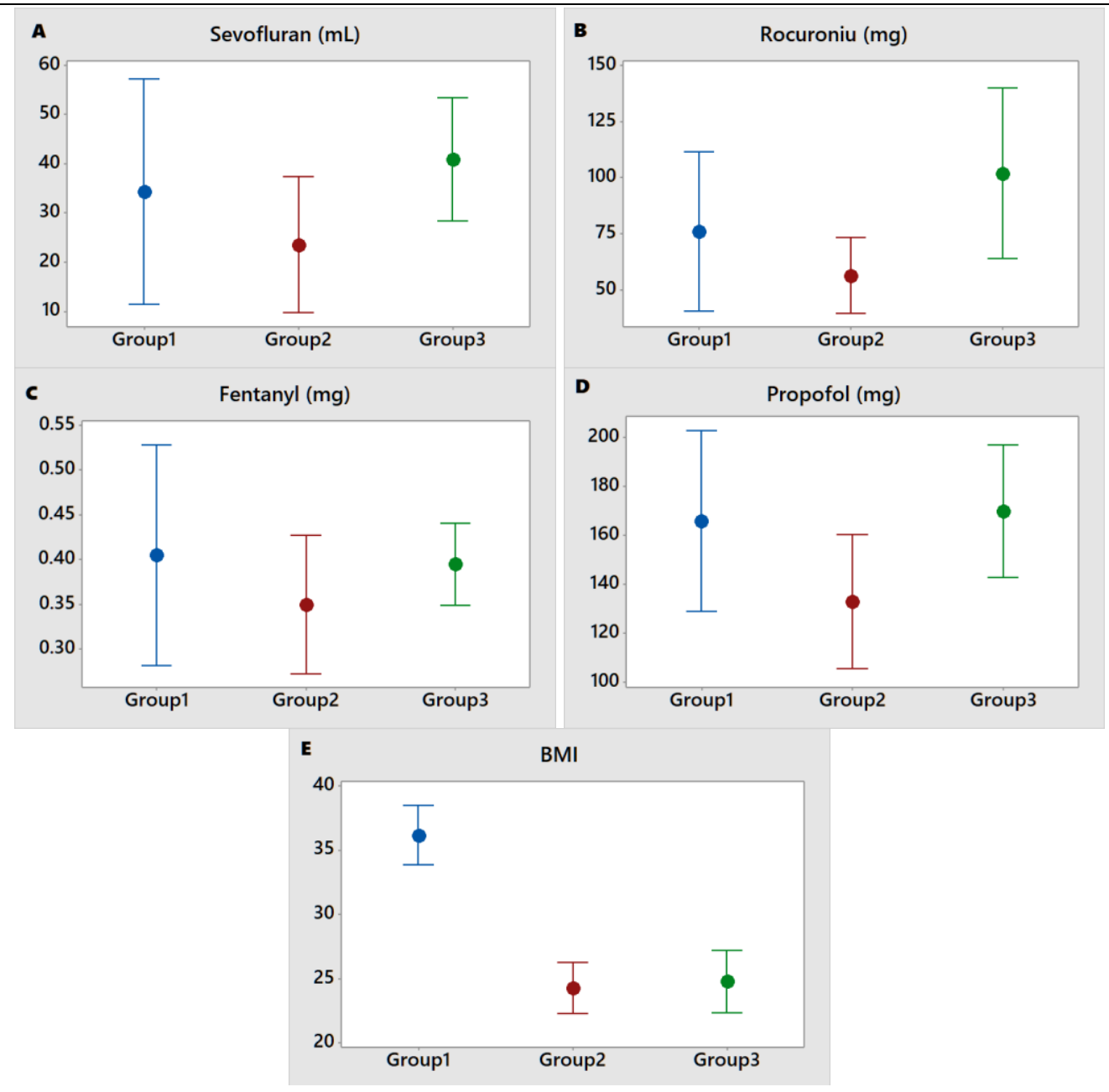

Figure 3.

A, B, C, D, E Interval plot of the intrasurgical anaesthetics, with $95 \%$ confidence intervals

Relative Differences (\%) vs Group 3 values

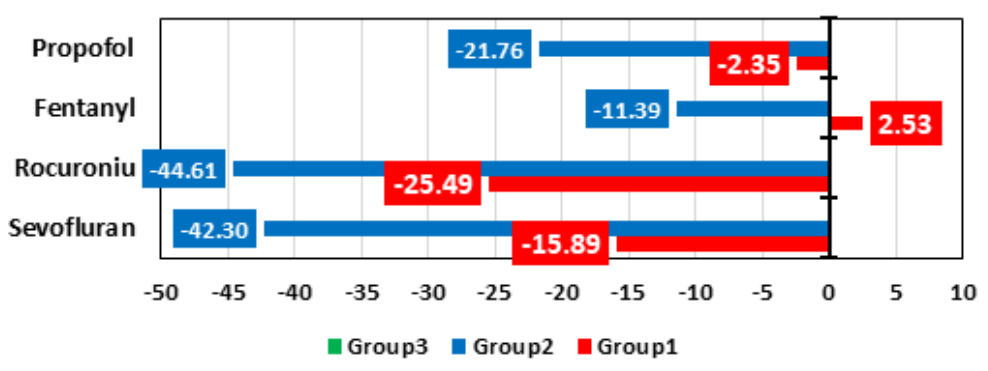

Figure 4.

Relative differences (\%) with group 3 values for the intrasurgical anaesthetics

The multivariate sequence (PCA, LDA and MANOVA $(\mathrm{P}=0.05))$ for the original data of the intrasurgical anaesthetics values started with the PCA method. In order to generate the best group comparisons, the PCA was performed with the correlation matrix and between group options.

These options generate results presented in Table $\mathrm{V}$ and the PCA biplot in Figure 5. As a useful graphical tool, in Figure 4 there were overlaid the $95 \%$ confidence ellipses; with this tool one can see if the group samples and ellipses are overlapping or not. In our case all three groups are overlapping. The variables vectors "tell" us the directions of the higher level for each analysed intrasurgical anaesthetics and their relative differences between the samples.

Table V

Principal components from PCA of the intrasurgical anaesthetics

\begin{tabular}{ccc}
\hline PC & Eigenvalue & \% variance \\
\hline $\mathbf{1}$ & 3.67271 & 91.818 \\
$\mathbf{2}$ & 0.327292 & 8.1823 \\
\hline
\end{tabular}




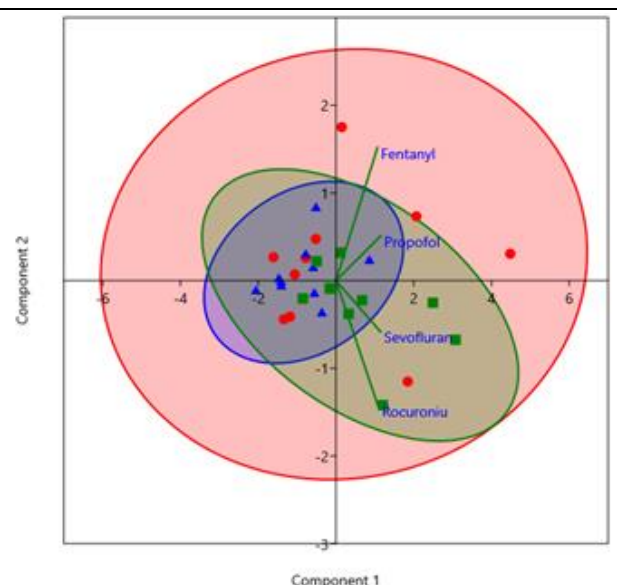

Figure 5.

Principal component (PCA) biplot of the intrasurgical anaesthetics and analysed groups There are represented the $95 \%$ confidence ellipses. Red dots are group 1 samples; Blue triangles are group 2

samples and green boxes are group 3 samples

Because the PCA is a multivariate method that emphasises the relative differences of variables levels of the analysed samples. Another multivariate method, LDA is used to emphasise the linear combinations between the variables that generates the best discrimination of the analysed samples. The LDA results presented in Figure 5, as a biplot, and the "quality" of the discrimination is presented as the confusion matrix in Table VI. All these results are in concordance with the PCA ones that stipulate no multivariate differences between the analysed groups.

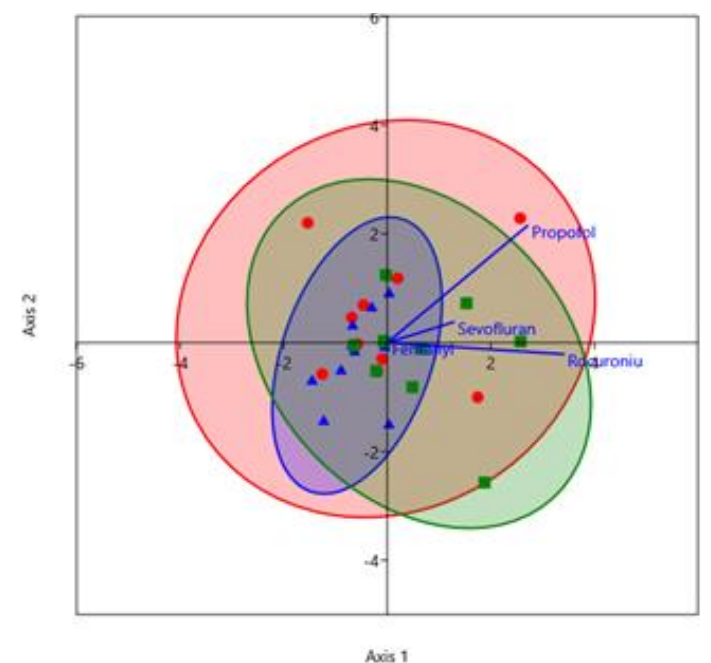

Figure 6.

Linear discriminant (LDA) biplot of the intrasurgical anaesthetics and analysed groups There are represented the $95 \%$ confidence ellipses. Red dots are group 1 samples; Blue triangles are group 2

samples and green boxes are group 3 samples

The multivariate methods PCA and LDA do not have a statistical significance level. For this reason, the MANOVA method was performed with $\mathrm{P}=0.05$ statistical significance level (Table VII). The pairwise group comparisons results prescribe that all the analysed groups are statistically not different.

Confusion matrix of the analysed groups from LDA (Linear Discriminant Analysis)

\begin{tabular}{cccc|c}
\hline Confusion Matrix & Group 1 & Group 2 & Group 3 & Total \\
\hline Group 1 & 2 & 6 & 2 & $\mathbf{1 0}$ \\
Group 2 & 5 & 4 & 1 & $\mathbf{1 0}$ \\
Group 3 & 4 & 2 & 4 & $\mathbf{1 0}$ \\
\hline Total & $\mathbf{1 1}$ & $\mathbf{1 2}$ & $\mathbf{7}$ & 30 \\
\hline
\end{tabular}

Table VII

Pairwise comparisons results from MANOVA $(\mathrm{P}=0.05)$ based on intrasurgical anaesthetics and analysed groups

\begin{tabular}{cccc}
\hline MANOVA & Group 1 & Group 2 & Group 3 \\
\hline Group 1 & & 0.5470 & 0.5099 \\
Group 2 & 0.5470 & & 0.2545 \\
Group 3 & 0.5099 & 0.2545 & \\
\hline
\end{tabular}

Clinically, the previous results mean that the entropy monitoring reduces the intrasurgical anaesthetics levels for DM condition patients in such way it can be "confused" with the non-DM condition patient groups. Still, group 2 (patients with entropy monitoring and without DM condition) is not discriminated from group
3 (patients without entropy monitoring and without DM condition). This issue is alleviated by normalizing the original data (intrasurgical anaesthetics levels) by the BMI levels.

All the previously presented univariate and multivariate methods were performed for the BMI normalized data. Results from Table VIII show that rocuronium and propofol are the variables that discriminate the analysed groups in the ANOVA's post hoc pairwise comparison test $(\mathrm{P}=0.05)$

Furthermore, Figure 9 shows high values of relative differences for all variables of group 1 and group 2, respecting the group 3 variable values. 
Table VIII

Mean values ( \pm standard deviation) of intrasurgical anaesthetics for the analysed patient groups $-\mathrm{BMI}$

\begin{tabular}{|c|c|c|c|c|}
\hline Group & $\begin{array}{c}\text { Sevoflurane } \\
(\mathbf{m L / B M I} \times \mathbf{1 0 0})\end{array}$ & $\begin{array}{c}\text { Rocuronium } \\
(\mathbf{m g} / \mathbf{B M I} \mathbf{~ 1 0 0})\end{array}$ & $\begin{array}{c}\text { Fentanyl } \\
(\mathbf{m g} / \mathbf{B M I} \mathbf{x} 100)\end{array}$ & $\begin{array}{c}\text { Propofol } \\
(\mathbf{m g} / \mathbf{B M I} \mathbf{x} 100)\end{array}$ \\
\hline Group 1 & $95.101 \mathbf{a} \pm 82.730$ & $208.950 \mathbf{b} \pm 120.025$ & $1.135 \mathbf{a} \pm 0.498$ & $460.616 \mathbf{b} \pm 126.512$ \\
\hline Group 2 & $94.175 \mathbf{a} \pm 60.213$ & $232.389 \mathbf{b} \pm 86.822$ & $1.449 \mathbf{a} \pm 0.417$ & $550.413 \mathbf{a b} \pm 154.356$ \\
\hline Group 3 & $171.319 \mathbf{a} \pm 85.198$ & $422.829 \mathbf{a} \pm 222.404$ & $1.625 \mathbf{a} \pm 0.353$ & $694.797 \mathbf{a} \pm 153.587$ \\
\hline
\end{tabular}

Different letters across columns for each variable denotes statistically significant differences between the samples means (Tukey's post hoc test). Results are expressed as mean \pm standard deviation $(n=10)$.

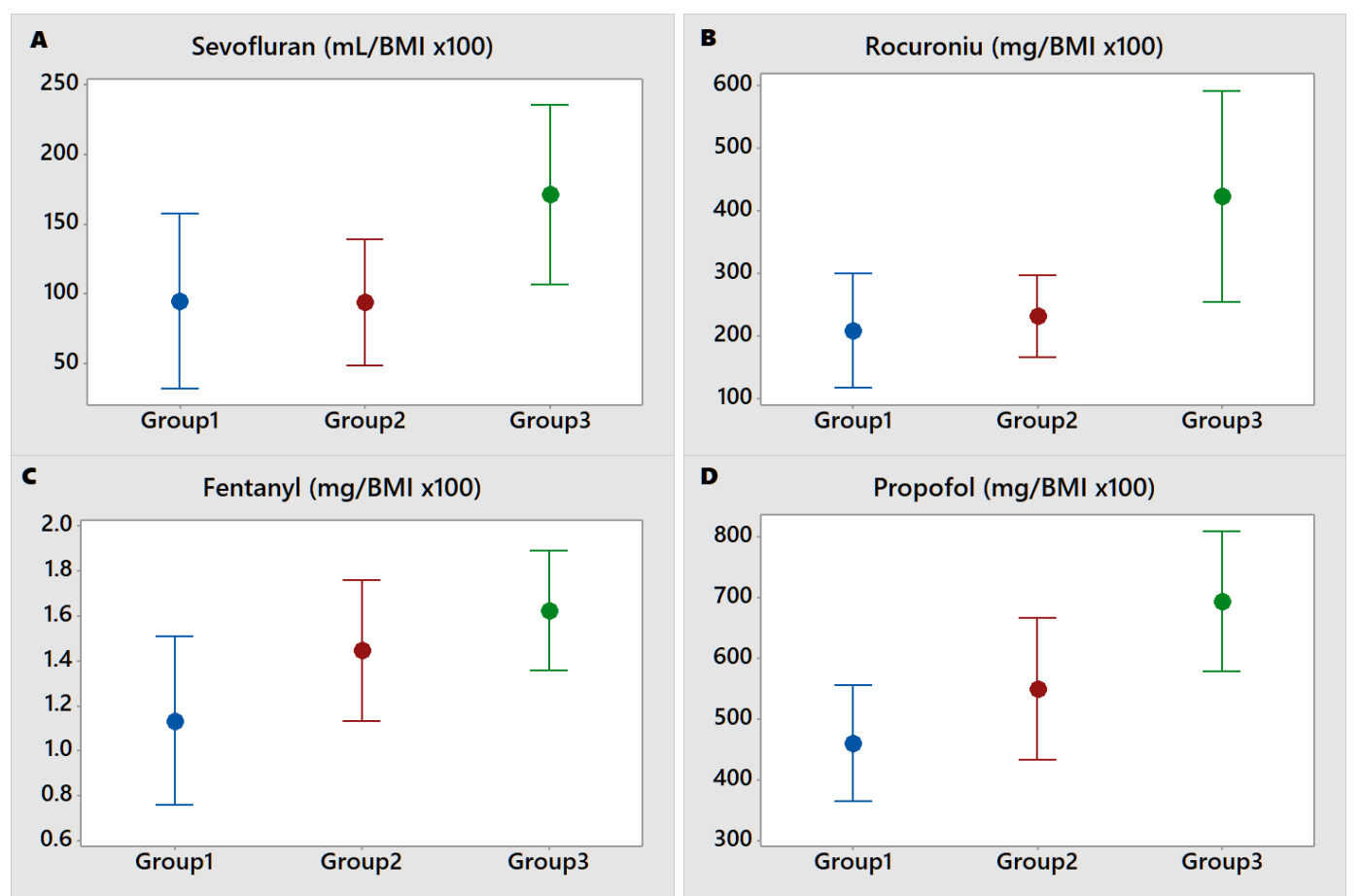

Figure 7.

A, B, C, D Interval plot of the BMI normalized intrasurgical anaesthetics, with 95\% confidence intervals

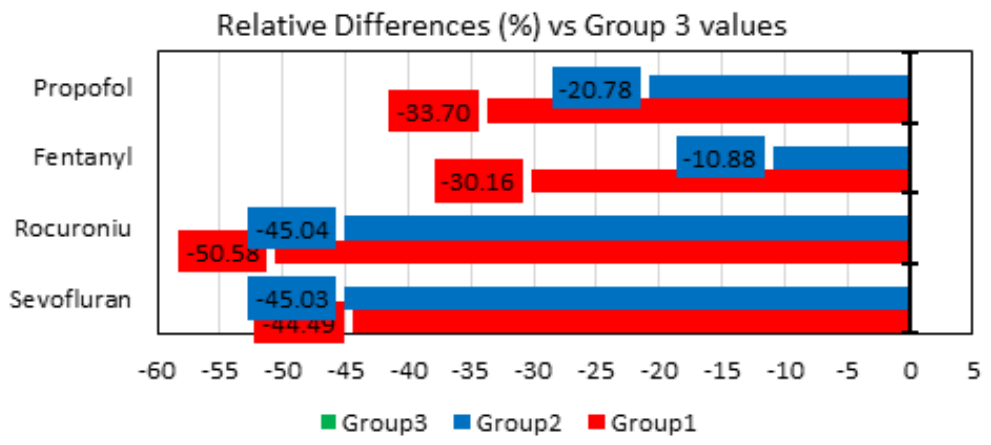

Figure 8.

Relative differences (\%) with group 3 values for the BMI normalised intrasurgical anaesthetics 


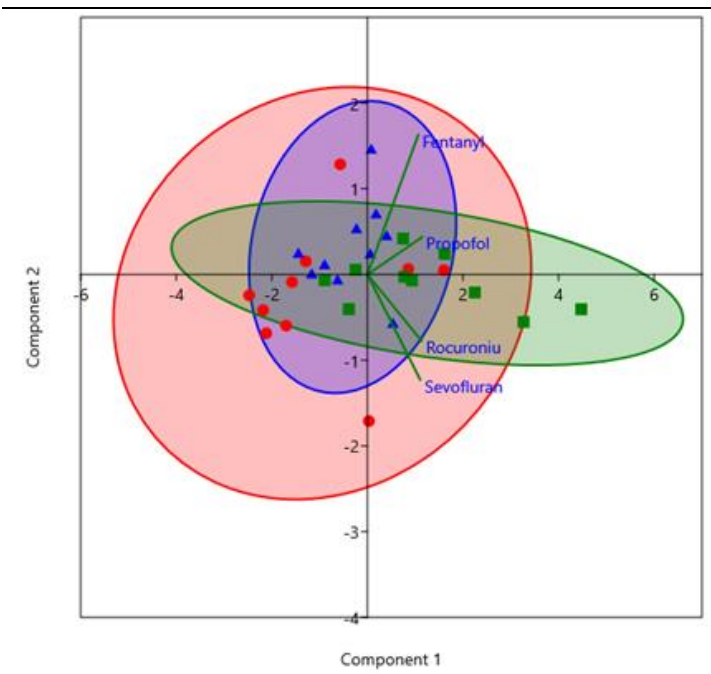

Figure 9.

Principal component biplot of the BMI normalised intrasurgical anaesthetics and analysed groups There are represented the $95 \%$ confidence ellipses. Red dots are group 1 samples; Blue triangles are group 2 samples and green boxes are group 3 samples

Table IX

Principal components from PCA of the BMI normalized intrasurgical anaesthetics

\begin{tabular}{ccc}
\hline PC & Eigenvalue & \% variance \\
\hline $\mathbf{1}$ & 3.72012 & 93.003 \\
$\mathbf{2}$ & 0.279882 & 6.997 \\
\hline
\end{tabular}

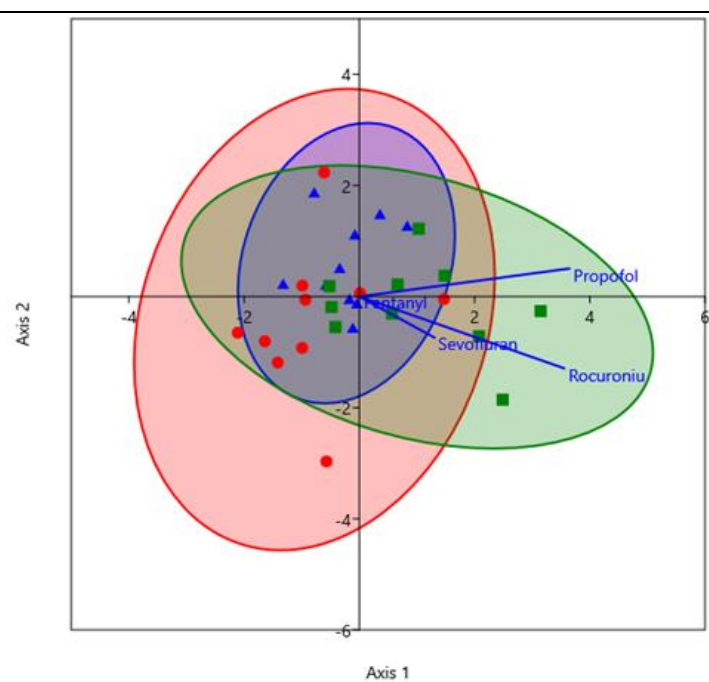

Figure 10.

Linear discriminant biplot of the BMI normalised intrasurgical anaesthetics and analysed groups

There are represented the $95 \%$ confidence ellipses. Red dots are group 1 samples; Blue triangles are group 2 samples and green boxes are group 3 samples

The MANOVA $(\mathrm{P}=0.05)$ multivariate test prescribes that group 1 and group 2 are statistically not different from each other, but different from group 3 (Table XI), as should be expected when was built up the design of the experiment.

Table X

Confusion matrix of the analysed groups from LDA (Linear Discriminant Analysis)

\begin{tabular}{cccc|c}
\hline Confusion Matrix & Group 1 & Group 2 & Group 3 & Total \\
\hline Group 1 & 7 & 2 & 1 & $\mathbf{1 0}$ \\
Group 2 & 6 & 3 & 1 & $\mathbf{1 0}$ \\
Group 3 & 2 & 2 & 6 & $\mathbf{1 0}$ \\
\hline Total & $\mathbf{1 5}$ & $\mathbf{7}$ & $\mathbf{8}$ & 30 \\
\hline
\end{tabular}

Table XI

Pairwise comparisons results from MANOVA $(\mathrm{P}=$ 0.05 ) based on BMI normalised intrasurgical anaesthetics and analysed groups

\begin{tabular}{cccc}
\hline MANOVA & Group 1 & Group 2 & Group 3 \\
\hline Group 1 & & 0.28317 & $\mathbf{0 . 0 3 7 2 5 3}$ \\
Group 2 & 0.28317 & & 0.11607 \\
Group 3 & $\mathbf{0 . 0 3 7 2 5 3}$ & 0.11607 & \\
\hline
\end{tabular}

Clinically, the previous results means that the entropy monitoring reduces the intrasurgical anaesthetics levels for DM condition patients, group 1, in such way it can be "confused" with the non-DM condition patient group 2, that has entropy monitoring, but both are statistically discriminated from the group 3, that is without entropy monitoring and DM condition.

Furthermore, the relative differences (Figure 8), prescribe significant intrasurgical anaesthetics level decreases for the entropy monitored patient groups, fact that allows the use in the DM patients as in the ones without the DM [6].

\section{Conclusions}

In this study we have shown that entropy reduces the use of intrasurgical anaesthetics in patients with metabolic disorders (diabetes and/or obesity) with almost $20 \%$ than the control group, so entropy provided them with a reduction of the need for anaesthetics and a much faster postoperative awakening, diminishing the number of hospitalization days for these patients, greatly reducing postoperative costs and complications due to comorbidities.

\section{Conflict of interest}

The authors declare no conflict of interest.

\section{References}

1. Aimé I, Verroust N, Masson-Lefoll C, Taylor G, Laloë PA, Liu N, Fischler M, Does monitoring bispectral index or spectral entropy reduce sevoflurane use? Anesth Analg., 2006; 103(6): 1469-1477. 
2. Andrade J, Deeprose C, Unconscious memory formation during anaesthesia. Best Pract Res Clin Anaesthesiol., 2007; 21(3): 385-401.

3. Ciurcanu OE, Stefanescu O, Scutariu MM, Stelea CG, Importance of the chemistry of local anesthetic in modulation of cardio-vascular response. Rev Chim (Bucharest), 2016; 67(3): 566-569.

4. El Hor T, Van der Linden P, De Hert S, Mélot C, Bidgoli J, Impact of entropy monitoring on volatile anesthetic uptake. Anesthesiology, 2013; 118(4): 868873.

5. Ellerkmann RK, Liermann VM, Alves TM, Kreuer S, Wilhelm W, Roepcke H, Hoeft A, Bruhn J, Spectral entropy and bispectral index as measures of the electroencephalographic effects of sevoflurane. Anesthesiology, 2004; 101(6): 1275-1282.

6. Hammer $\varnothing$, Harper DAT, Ryan PD, PAST: Paleontological statistics software package for education and data analysis. Palaeontol Electron., 2001; 4(1): $1-9$.

7. www.nice.org.uk/guidance/dg6/documents/depthof-anaesthesia-monitors-eentropy-bis-andnarcotrend-scope2, National institute for Health and Clinical Excellence Diagnostics Assessment Programme Assessment of Depth of Anaesthesia monitors - Final scope, November 2011.

8. www.srati.ro/departamentul-de-educatie-medicalasi-cercetare/studii/modulation-of-generalanesthesia-using-entropy-and-surgical-pleth-indexesptr.

9. www.asahq.org/standards-and-guidelines/asaphysical-status-classification-system.

10. Lennmarken C, Bildfors K, Enlund G, Samuelsson P, Sandin R, Victims of awareness. Acta Anaesthesiol Scand., 2002; 46(3): 229-231.

11. Lupu MN, Miulescu M, Stefanopol IA, Stoleriu G, Matei MN, Manolache N, Vasincu D, Ciobotaru OR, Costuleanu M, Effect of 2,6-diisopropylphenol and 1,1,1,3,3,3-hexafluoro-2- (fluoromethoxy) propane as Anesthetic. Rev Chim (Bucharest), 2019; 70(5): 1888-1892.

12. Mehmood MH, Malik A, Akhtar MS, Haider G, Gilani AH, Antihyperglycaemic, antihyperlipidaemic and antihypertensive effect of a polyherbal formulation in alloxan-induced diabetic rats. Farmacia, 2020; 68(5): 882-890.

13. O'Connor MF, Daves SM, Tung A, Cook RI, Thisted $\mathrm{R}$, Apfelbaum J, BIS monitoring to prevent awareness during general anesthesia. Anesthesiology, 2001; 94(3): 520-522.

14. Osterman JE, Hopper J, Heran WJ, Keane TM, Van der Kolk BA, Awareness during anesthesia and the development of posttraumatic stress disorder. Gen Hosp Psychiatry, 2001; 23(4): 198-204.

15. Pertea M, Grosu OM, Veliceasa B, Velenciuc N, Ciobanu P, Tudor R, Poroch V, Lunca S, Effectiveness and safety of wide awake local anesthesia no tourniquet (WALANT) technique in hand surgery. Rev Chim (Bucharest), 2019; 70(10): 3587-3591.

16. Vakkuri A, Yli-Hankala A, Talja P, Mustola S, Tolvanen-Laakso H, Sampson T, Viertiö-Oja H, Time frequency balanced spectral entropy as a measure of anesthetic drug effect in central nervous system during sevoflurane, propofol and thiopental anesthesia. Acta Anaesthesiol Scand., 2004; 48(2): 145-153.

17. Viertiö-Oja H, Maja V, Särkelä M, Talja P, Tenkanen N, Tolvanen-Laakso H, Paloheimo M, Vakkuri A, Yli-Hankala A, Meriläinen P, Description of the Entropy algorithm as applied in the Datex-Ohmeda S/5 Entropy Module. Acta Anaesthesiol Scand., 2004; 48(2): 154-161.

18. Yücel UM, Öner AC, Türel İ, Yilmaz O, Drug interaction between ivermectin and etomidate: investigation on the effect of ivermectin on etomidate anaesthesia. Farmacia, 2020; 68(5): 925-931.

19. www.ema.europa.eu/en/documents/productinformation/. 